\title{
The Efficiency Patterns of Islamic Banks During the Global Financial Crisis The Case of Bangladesh
}

Asmild, Mette; Kronborg, Dorte; Mahbub, Tasmina; Matthews, Kent

\author{
Document Version \\ Accepted author manuscript \\ Published in: \\ The Quarterly Review of Economics and Finance
}

DOI:

10.1016/j.qref.2018.04.004

Publication date:

2019

License

CC BY-NC-ND

Citation for published version (APA):

Asmild, M., Kronborg, D., Mahbub, T., \& Matthews, K. (2019). The Efficiency Patterns of Islamic Banks During the Global Financial Crisis: The Case of Bangladesh. The Quarterly Review of Economics and Finance, 74, 6774. https://doi.org/10.1016/j.qref.2018.04.004

Link to publication in CBS Research Portal

\section{General rights}

Copyright and moral rights for the publications made accessible in the public portal are retained by the authors and/or other copyright owners and it is a condition of accessing publications that users recognise and abide by the legal requirements associated with these rights.

\section{Take down policy}

If you believe that this document breaches copyright please contact us (research.lib@cbs.dk) providing details, and we will remove access to the work immediately and investigate your claim. 


\title{
The Efficiency Patterns of Islamic Banks During the Global Financial Crisis: The Case of Bangladesh
}

\author{
Mette Asmild, Dorte Kronborg, Tasmina Mahbub, and Kent Matthews
}

Journal article (Accepted manuscript*)

\section{Please cite this article as:}

Asmild, M., Kronborg, D., Mahbub, T., \& Matthews, K. (2018). The Efficiency Patterns of Islamic Banks During the Global Financial Crisis: The Case of Bangladesh. The Quarterly Review of Economics and Finance.

DOI: 10.1016/j.qref.2018.04.004

DOl: 10.1016/j.aref.2018.04.004

* This version of the article has been accepted for publication and undergone full peer review but has not been through the copyediting, typesetting, pagination and proofreading process, which may lead to differences between this version and the publisher's final version AKA Version of Record.

Uploaded to CBS Research Portal: March 2019

(C) 2019. This manuscript version is made available under the CC-BY-NC-ND 4.0 license http://creativecommons.org/licenses/by-nc-nd/4.0/ 


\title{
The Efficiency Patterns of Islamic Banks during the Global Financial Crisis:
}

\section{The Case of Bangladesh}

Mette Asmild (University of Copenhagen)

Dorte Kronborg (Copenhagen Business School)

Tasmina Mahbub (Cardiff Business School)

Kent Matthews (School of Public Finance and Taxation, Zhongnan University of Economics \& Law, PR China and Cardiff Business School)

March 2018

\section{Highlights}

- This paper examines the inefficiency patterns of Islamic Banks relative to conventional banks during the Global Financial Crisis in Bangladesh.

- It uses the novel method of Multi-directional Efficiency Analysis (MEA) to identify the specific factors that contribute to efficiency differences.

- The paper meets the criticism that multi-country studies are invalid through the inconsistent application of Sharia across countries by focussing on a single country.

\begin{abstract}
The Global Financial Crisis (GFC) has refocussed attention on Islamic banking as an alternative business model for banking. Studies of the performance of Islamic banks during the Global Financial Crisis have typically used one-step or two-step methods based on Data Envelopment Analysis (DEA) with mixed results. But such techniques are limited by the inability to identify the nature and structure of the inefficiencies with respect to the improvement potentials on different variables. In this paper we apply Multi-directional Efficiency Analysis (MEA) which facilitates an understanding of the differences in inefficiency patterns for a set of banks in Bangladesh from 2001-2015. We confirm the consensus finding that Islamic banks outperformed conventional commercial banks during the GFC period but additionally identify differences in inefficiency from specific variables. Such information can provide important insights to managers and regulators.
\end{abstract}

Keywords: Islamic banks, Multi-directional Efficiency Analysis (MEA), Bangladesh. 


\section{JEL Codes: C650, G210, G290}

Paper prepared for the $9^{\text {th }}$ Foundation of Islamic Finance Conference (FIFC 2017), 25-26 September Lancaster University Management School.

We are grateful to the Editor and two anonymous referees for helpful comments. All remaining errors are ours entirely

We acknowledge funding for this research from the Mahbub Ahmed Foundation

\section{Introduction}

The Global Financial Crisis (GFC), which has left much of the Western banking system in a parlous state, has once again placed the spotlight on alternative models of banking. Islamic banking with its emphasis on ethical investment and prohibition of derivative products is a natural focus for a comparative study. Studies of relative performance of Islamic banks against conventional banks have typically focussed on issues of efficiency and profitability ${ }^{1}$. However, the financial crisis has spawned a flurry of research activity that has focussed on the performance of Islamic banks specifically during the crisis years. Recent studies have gone beyond the narrow issue of efficiency and performance and have also examined stability, capital adequacy, competitiveness and risk $^{2}$, but efficiency remains the predominant focus of investigation.

While Islamic banking has an ancient pedigree that draws from the principles of Sharia law and has been practiced in the Muslim world since the Middle Ages ${ }^{3}$, its emergence in the world of practical banking has been only since the middle of the $20^{\text {th }}$ century. Its emergence in the Bangladesh banking landscape has been even more recent with the establishment of the Islami

\footnotetext{
${ }^{1}$ See for example Bashir (1999), Samad (1999), Yudistra (2004), Hassan (2006), Bader et al (2008) to name but a few.

${ }^{2}$ Abdul-Karim et al (2014) on capital adequacy, lending and financing behaviour, Čihăk and Hesse (2010) on financial stability, and Ariss (2010) on competitive conditions.

${ }^{3}$ See Zaher and Hassan (2001) for a comprehensive review of Islamic finance and banking.
} 
Bank Bangladesh Ltd in $1983^{4}$. Since then Islamic banking has grown rapidly in size, employment and branch network, capturing market share from the original privatised banks. But despite being a predominantly Muslim country, Islamic banking remains in a minority position in terms of asset share (18\% in 2015, cf. Table 1 in Section 2.2 below).

Bangladesh is a suitable testbed for the study of the performance and efficiency patterns of Islamic banks during the GFC for three reasons. First, as has been already stated, Islamic banks are relative newcomers to the banking sector in Bangladesh and therefore faced a steeper learning curve in terms of market penetration and the implementation of Sharia compliant financial products. Second, the Islamic Bank sector has grown rapidly in size in a relatively short space of time (from $8 \%$ of bank assets in 2001 to $18 \%$ in 2015, cf. Table 1) signalling the fertile environment in which it has been able to expand but inevitably raising questions about the quality of loans and the veracity of its risk management ${ }^{5}$. Third, the Bangladesh banking system has gone a through a period of reform and deregulation in the three decades up to 2015 that has resulted in an increase in foreign entry, competition, asset growth and stricter governance procedures. These reforms will in different ways have impacted the efficiency patterns of the banking system and of the different types of banks within the sector.

The standard approach to the measurement of efficiency in banking has been to employ either parametric (Stochastic Frontier Analysis (SFA)) or non-parametric methods with Data Envelopment Analysis (DEA) being the favourite amongst the latter. By far the most common technique used to analyse the efficiency of Islamic banks has been DEA. However, the interpretation and application of DEA results can be limited by the fact that radial improvement potentials are identified across the input and/or output variables. Asmild and Matthews (2012) have shown how the use of Multi-directional Efficiency Analysis (MEA) (see also Bogetoft and Hougaard 1999 and Asmild et al. 2003) facilitates an understanding of the differences in the nature and structure of the estimated inefficiencies.

\footnotetext{
${ }^{4}$ See Hassan (1999) for a case study of the IBBL.

${ }^{5}$ In reality, Islamic banks had a lower NPL ratio than conventional banks in 2015.
} 
The focus of this paper is simple. Its purpose is to measure the patterns and differences in inefficiency between Islamic and non-Islamic banks in Bangladesh during the Global Financial Crisis. In this aim, the paper employs MEA, which allows us to go further than DEA to undertake the analysis of variable-specific efficiencies. This method is applied to the private commercial banks in Bangladesh to identify the differences in inefficiency patterns between Islamic and non-Islamic banks in the period 2001-2015. In general, we find almost no significant difference in the inefficiency patterns between Islamic and non-Islamic banks for the period outside the depth of the GFC. However, we find significantly higher efficiencies of both the inputs (non-labour costs and labour costs) as well as one of the outputs in the time window of the GFC period for the Islamic banks compared to the private conventional banks.

This paper is organised in the following way. The next section reviews the literature on the performance of Islamic banks in the GFC period, and Islamic banks in Bangladesh in particular. It also outlines in brief the structure of the Bangladesh banking system and motivates the analysis of the period of the GFC for comparative performance of the two types of banks. The third section outlines the methodology of MEA. The fourth section presents the data and the results. The final section concludes with a discussion of the implications of the results.

\section{Islamic Banks and Bangladesh Banking}

\subsection{Islamic Banks and the GFC}

The comparative performance of Islamic Banks (IB) and Conventional Banks (CB) has been a regular area of research in the banking literature ${ }^{6}$, but as Beck et al (2013) has indicated, consensus in the findings is difficult because of the heterogeneity in implementation of Sharia compliant products across different countries. This makes it difficult to draw valid inferences

\footnotetext{
${ }^{6}$ For example, Abdul-Majid et al (2005), Al-Jarrah and Molyneux (2005), El-Genial and Hulusi (2005), Chong and Liu (2009), Abdul-Majid et al (2009) (2010) and Srairi (2010). For a comprehensive review see Brown et al (2007).
} 
from cross country studies that do not allow for significant cross-country variation. However, a number of studies have been published on the performance of Islamic banks during, and/or including the GFC period. A cross-country study of profitability was conducted by Hassan and Dridi (2010) who estimate profit functions with country dummies for 120 banks, of which a quarter are IBs and the rest CBs, across eight countries, for the period 2007-10. They find that in general IBs performed better than CBs in 2008 but weaknesses in risk management practices meant that as the global economy downturned in 2009, IBs performed worse than CBs. Beck et al (2013) examine a range of indicators for 522 banks over 22 countries, covering business orientation, efficiency, asset quality and stability measured by the familiar z-score, with a mixture of results. There was no difference in the measures of business models between IBs and CBs in the sample period 2005-2009. They found that IBs were less efficient but had better asset quality and stronger capitalisation which helped them to perform better during the crisis.

Using the z-score as a measure of stability for a matched sample of 34 IBs and $34 \mathrm{CBs,} \mathrm{Bourkhis}$ and Naqbi (2014) find that there was no difference between the two types of banks during the GFC. They conclude that IBs match CBs in their business model and fail to distance themselves from conventional banking by delivering financial products that are not fully Sharia compliant ${ }^{7}$. Two-stage approaches are used to analyse the performance of IBs by Rosman et al (2014) and Johnes et al (2014). The first study uses DEA to measure technical efficiency of 79 Middle Eastern and Asian IBs in the 2007-10 period. The second stage involves the explanation of technical efficiency, pure technical efficiency and scale efficiency using bank-specific variables in an econometric model. The finding is that Islamic banks are scale inefficient and operate at decreasing returns to scale. However, it can be argued that besides violating the Simar and Wilson (2007) critique of the 2-stage approach, the study does not include any CBs in the sample. This criticism is rectified by Johnes et al (2014), who dig deeper to examine a sample of IBs and CBs for the period 2004-2009. They follow the DEA bootstrap procedure of Simar and Wilson (2008) to obtain efficiency scores which are decomposed further using metafrontier analysis (MFA), into net efficiency and type efficiency. The former is efficiency

\footnotetext{
${ }^{7}$ A similar argument is made by Chong and Liu (2009) that only a small portion of Malaysian IBs are based on profit-loss sharing and being interest rate free.
} 
relative to each bank's own bank type frontier while the latter relates to the efficiency defined by the operational constraints the business functions under. They find that IBs are on par with CBs in terms of gross efficiency but have a higher net efficiency but lower type efficiency. The former is taken as an indication of higher managerial efficiency while the latter indicates constraints that are IB specific.

Multi-country studies of IB versus CB performance are questionable because of the heterogeneity of the implementation of Sharia compliant instruments in practice, as noted by Beck et al (2013). It may therefore be invalid to generalise on the performance of IBs as a group across all countries. This makes the study of Islamic banks and their performance within a single country framework, all the more valid.

While there have been a number of studies that have examined the efficiency and performance of banks in Bangladesh ${ }^{8}$, to our knowledge none have examined the performance of IBs and CBs in the GFC period specifically. Sufian and Kamarudin $(2013,2014)$ use DEA $^{9}$ to examine bank profit efficiency in the period covering the GFC period but the data set of 31 banks contains only 3 IBs. The year 2008 was the peak for average profit efficiency in the period 2004-2011 but consistent with the findings of Beck et al (2013), performance dropped sharply in 2009 is response to the second-round effects of the GFC on the global economy.

More recently Robin et al (2018) and Hossain Raju (2017), use SFA to model cost efficiency and cost and profit efficiency respectively for banks in Bangladesh. The former study models an inefficiency function as part of the cost function to examine the effect of financial reforms

\footnotetext{
${ }^{8}$ Safiullah (2010), Rashid and Nishat (2009), Sarker (1999) use accounting ratio analysis to examine the performance of Islamic banks and non-Islamic commercial banks in Bangladesh. Ahmad and Hassan (2007) use ratio analysis to examine the performance of IBs alone.

${ }^{9}$ Abduh et al (2013) use DEA to examine the efficiency of IBs in Bangladesh but little can be gleaned from the study which uses only five banks in the data set, violating all the rules of dimensionality in DEA. Hoque and Rayhan (2013) go further to take 21 banks in 2009, with one output (profit) and 4 inputs including income and costs and erroneously conclude that VRS is the appropriate methodology for such a small sample. A sophisticated study by Akther et al (2013) that uses network-DEA examines the bias in black-box DEA for the period 20052008. They find that average inefficiency declined in 2008.
} 
over three stages in the period 1983-2012, using 12 commercial banks ${ }^{10}$. The post-reform (1996-2012) and transition (1991-1995) periods exhibit a faster improvement in cost efficiency compared with the pre-reform period (1983-1990). The latter study includes State-owned Commercial Banks (SOCBs) with CBs and IBs for the period 2011-2015 and conclude that CBs are more profit and cost efficient than IBs or SOCBs but without providing statistical significance to support this conclusion.

Our study is the first of its kind in its application to Bangladesh. It not only examines the efficiency differences, but also the efficiency patterns of Islamic and non-Islamic banks in the context of the Global Financial Crisis using the relatively novel method of MEA as opposed to the familiar DEA or SFA technique in addressing this issue. In using MEA it explicitly identifies the sources of the efficiency differences.

\subsection{Bangladesh Banking}

The Bangladesh economy was not immune to the Global Financial Crisis and like many emerging economies was indirectly affected by the slowdown in the world economy, in its aftermath. Figure 1 shows that the GDP growth fell sharply from a peak of 7 per cent in 2007 to 5 per cent in 2009. This was driven by a sharp fall in export growth which fell from a threeyear average of 14 per cent per year to 2007, to 7 per cent in 2008 and 9.8 per cent in 2009 . For an economy with an average level of 'openness' (exports plus imports as \% of GDP) of 40\%, (Bangladesh Bureau of Statistics) this will have been a significant negative shock, contributing to a sharp decrease in net trade, and a growth slowdown. Bangladesh suffered only a growth slowdown during the GFC. But figure 2 shows the corresponding 'Lucas wedge', i.e. the gap between the trend the GDP exhibited in the peak in 2007 and the actual real GDP (both on a $\log$ scale). This gap will take several years to be eliminated. While a direct link between the impacts of the GFC on the banking sector in Bangladesh through its effect on the economy, is difficult to pinpoint, it is safe to assume that there was an effect ${ }^{11}$.

\footnotetext{
${ }^{10}$ In keeping with studies such as Isik and Hassan (2003) a relatively long period is required for reforms to impact on bank technology.

${ }^{11}$ For a fuller discussion of the impact of the GFC on the Bangladesh economy, see Rahman et al (2009)
} 
Figure 1: Real GDP Growth \% 1997-2016

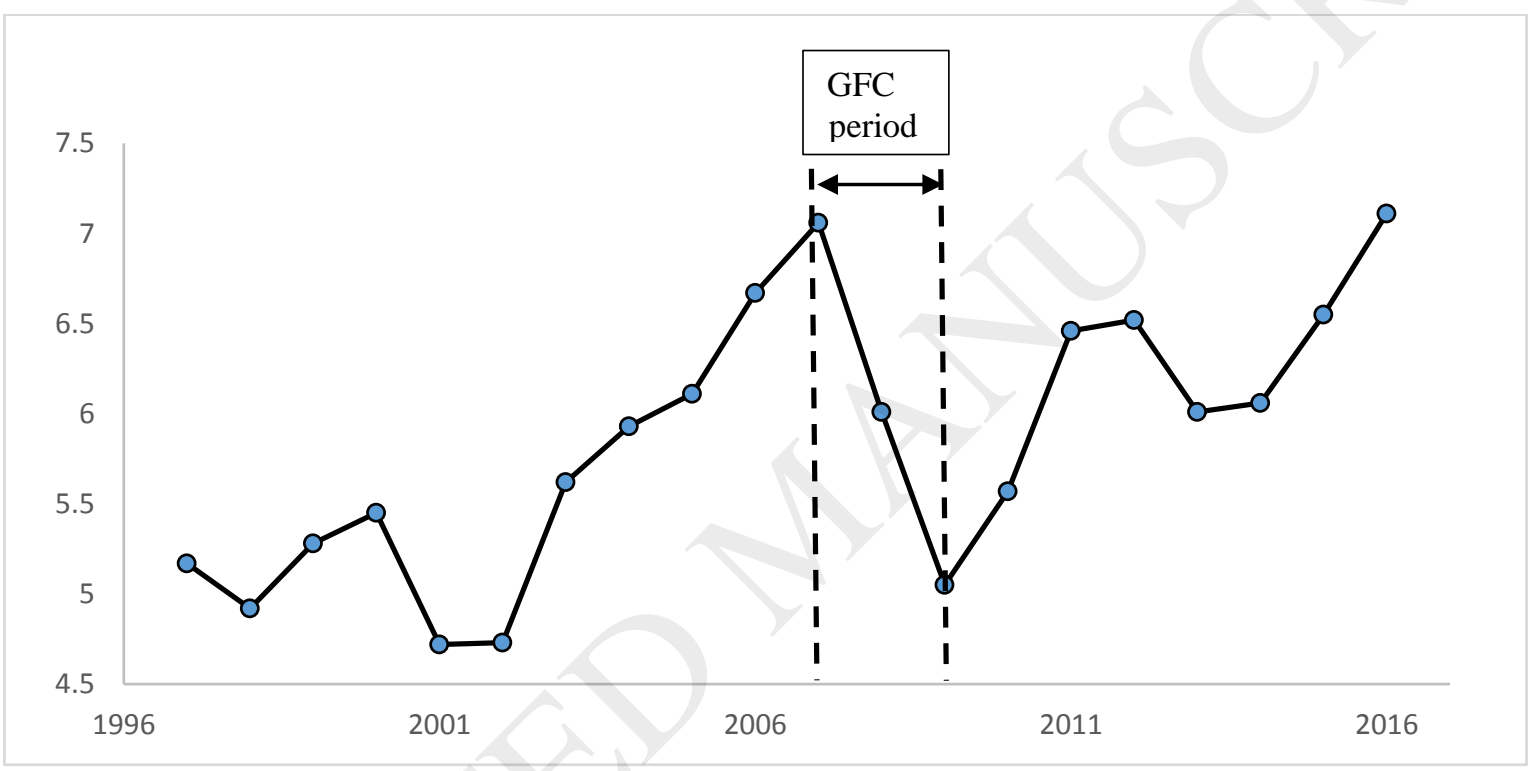

Source: Bangladesh Bureau of Statistics and IMF

Figure 2: Lucas wedge; Gap between trend and real GDP (log scale) 2006-2016 


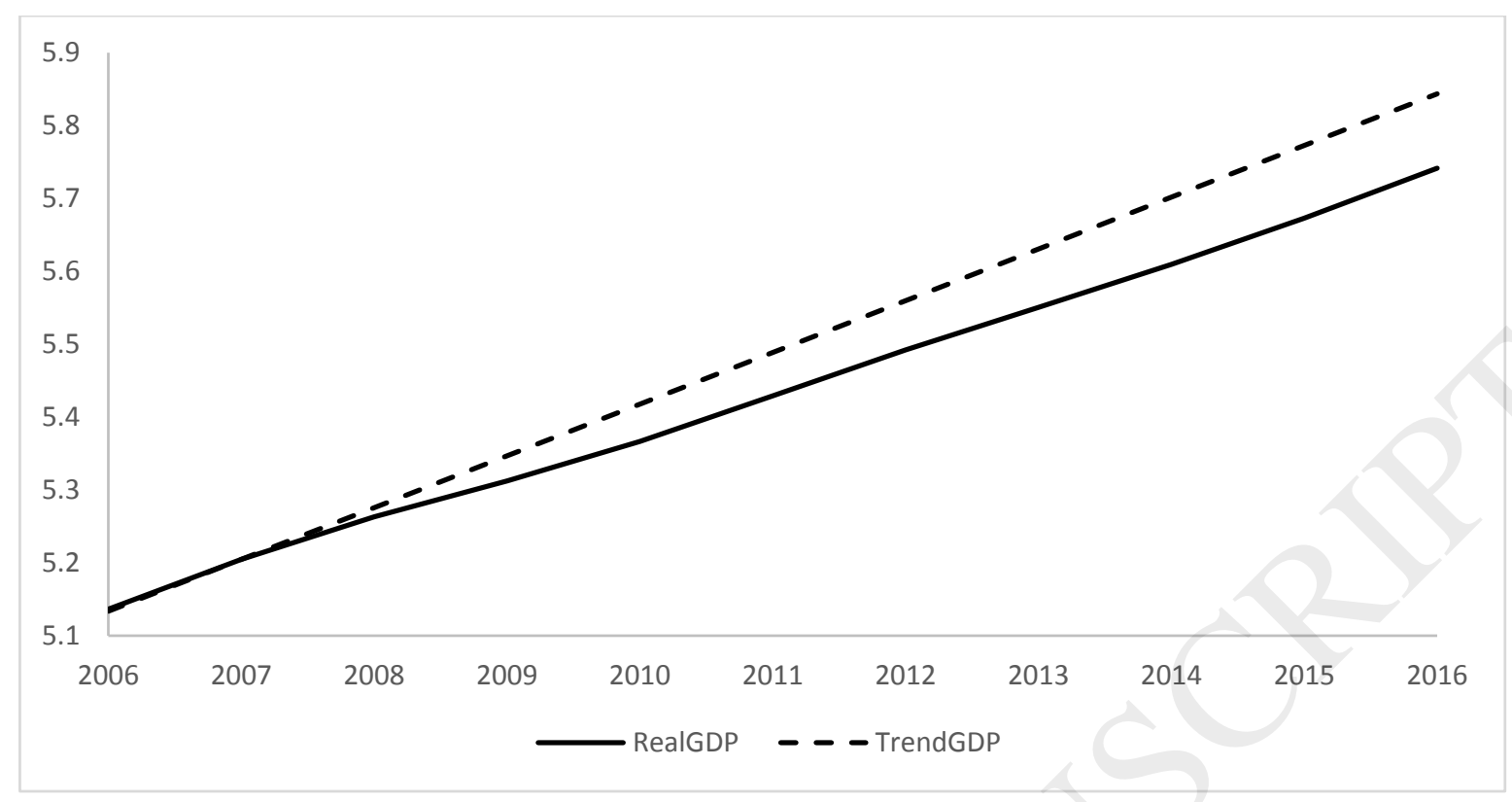

Source: Bangladesh Bureau of Statistics and author calculations

The banking sector of Bangladesh is made up of four categories of banks: State Owned Commercial Banks (SOCBs), State-owned Development Financial Institutions (SDBs), Private Commercial Banks (PCBs), which in turn can be separated into private Conventional Banks (CBs) and Islamic Banks (IBs), ${ }^{12}$ and finally Foreign Commercial Banks (FCBs).

In 2015 a total of 39 PCBs comprising 4226 branches, with Tk. 6652.9 billion of assets had $64.5 \%$ of the share of total bank assets in Bangladesh (Bangladesh Bank, 2017). The SOCBs and SDBs, together controlled $30.3 \%$, and the FCBs had $5.2 \%$ of the market ${ }^{13}$. Private Commercial Banks were first established during the 1980's and were classified by their operations regarding interest charging structure as either conventional banks (CBs) or Islamic banks (IBs). By 2015, 31 CBs operated in the banking sector of Bangladesh together with 8 Islami Sharia based banks. The CBs can be further grouped into 3 generations based on their year of establishment. First generation banks were those established between 1982 and 1990. They began their journey in 1982 when ownership and control was transferred from the public

\footnotetext{
${ }^{12}$ For a recent report on the state of Islamic banks in Bangladesh see Yousuf et al (2014).

${ }^{13}$ The market share of FCBs have fallen from $8 \%$ in 2001. Because they remain branches of their home institutions data relating to Bangladesh is unavailable and are therefore excluded from the sample https://www.bb.org.bd/pub/archive.php
} 
to private sector. Second generation banks were those established between 1991 and 1998, and third generation banks were those established after 1998.

It is well known that in general, state-owned banks operate under a different business model than private commercial banks (Megginson, 2005). While the SOCBs in Bangladesh have a share of banking assets of $28 \%$ in 2015 , the recognition that they have different objectives and cost constraints from private commercial banks justifies their exclusion from the sample of our study. Foreign banks have been operating in Bangladesh since her independence in $1971^{14}$. In 2001 they had 7\% of the market share of bank assets and the PCBs had 35\%. By 2015 the PCBs had nearly doubled the share of the market, largely at the expense of the SOCBs which had fallen from $47 \%$ in 2001 to $28 \%$ in 2015.

This paper focuses on the activity of the Islamic banks (IBs) and the private conventional banks $(\mathrm{CBs})$. The 1st generation of CBs were established under a lax regulatory environment, whereby the initial endowment of banking knowledge was weak. Poor training and regulation gave the first-generation banks little in the form of guidance on lending criteria or "fit and proper' corporate governance. The incentive system stressed disbursements rather than recoveries, and the accounting and debt collection systems were not developed to deal with the problems of loan recovery. It was more common for borrowers to default on loans than to repay; the lending system was effectively a mechanism for disbursing grant assistance to private individuals who qualified for loans on political rather than economic grounds (Islam et al, 2014). The rate of recovery on agricultural loans was only 27 per cent in 1986 and the rate on industrial loans was even lower. Similarly, the lending rates on priority sectors were kept deliberately low, which did not cover the risk and cost (Chowdhury and Ahmed, 2009; Islam et al, 2013; Islam et al, 2014). Thus, interest ceilings and financial repression was one of the main causes of weak performance resulting in high NPLs and low profitability.

\footnotetext{
${ }^{14}$ https://www.bb.org.bd/fnansys/bankfi.php
} 
Following pressure from the IMF to strengthen internal bank management and credit discipline, the Banking Companies Act 1991 was enacted and 1st generation CBs (GEN1) operated under the new laws. In general, 1st generation banks had a larger capital base, a larger client base and higher reserve than the 2nd and 3rd generation banks (GEN23) that followed. But one additional feature that separates GEN1 banks from GEN23 banks is that the former have a corporate governance structure of a board of directors with family connections. This difference in governance structure gives rise to differences in credit and risk management behaviour between the two (Mahbub et al, 2017) that results in significant differences in performance. Hence the CBs are not a homogeneous group and aggregating them as one group is theoretically inappropriate and may make it difficult to identify statistical differences with IBs. We therefore only distinguish between the GEN1 banks, and the later instituted GEN23 banks, whose performances are compared to that of the Islamic banks in the following.

Along with the implementation of the new banking laws, the rate of growth of assets of the banking system increased rapidly ${ }^{15}$. The 2 nd and 3rd Generation banks introduced greater account transparency in keeping with the Bank Company Act, 1991 and instituted tighter risk management (Chowdhury and Ahmed, 2009; Islam et al, 2014). Table 1 describes the share and change of assets in 2001 and 2015 for the different bank types.

\section{Table 1: Bangladesh banks 2001-2015}

\begin{tabular}{|l|l|l|l|l|}
\hline & Bank group & 2001 & 2015 & $2015-2001$ \\
\hline \multirow{3}{*}{$\begin{array}{l}\text { Share of total } \\
\text { bank assets\% }\end{array}$} & GEN1 & $13.5 \%$ & $13.0 \%$ & $-0.5 \%$ \\
\cline { 2 - 5 } & GEN23 & $13.6 \%$ & $33.2 \%$ & $+19.6 \%$ \\
\cline { 2 - 5 } & IB & $7.8 \%$ & $18.3 \%$ & $+10.5 \%$ \\
\hline \multirow{3}{*}{ NPL ratio \% } & GEN1 & $21.9 \%$ & $5.0 \%$ & $-16.9 \%$ \\
\cline { 2 - 5 } & GEN23 & $6.3 \%$ & $5.0 \%$ & $-1.3 \%$ \\
\cline { 2 - 5 } & IB & $7.3 \%$ & $3.2 \%$ & $-4.1 \%$ \\
\hline \multirow{3}{*}{ Branches } & GEN1 & 841 & 1229 & 388 \\
\cline { 2 - 5 } & GEN23 & 258 & 1730 & 1472 \\
\cline { 2 - 5 } & IB & 192 & 921 & 729 \\
\hline
\end{tabular}

\footnotetext{
${ }^{15}$ Asset growth of the commercial banks over the period 2001 to 2015 was around $21 \%$ a year.
} 
Table 1 shows that the IBs have gained market share along with the GEN23 banks at the expense of the GEN1 banks. IBs increased their market share by expanding their balance sheet but also, by increasing their branch network. Loan growth was in line with the banking system, but IBs were more successful in managing their NPL ratio, belying the suggestion that the rapid expansion in loans was at the expense of quality.

\section{Methodology}

\subsection{Multi-directional Efficiency Analysis}

Multi-directional Efficiency (MEA) was introduced by Bogetoft and Hougaard (1999) and operationalized by Asmild et al. (2003). Unlike the more commonly used DEA which considers radial improvements of all variables, MEA investigates the improvement potentials in each input dimension and identifies a benchmark proportional to these potential improvements. This results in a more nuanced picture of the inefficiency which may provide opportunities for additional conclusions about the presence and location of the inefficiency.

In order to formally define the MEA methodology, let $N$ be the set of observations, here banks, where each observation $j \in N$ uses $m$ inputs $x_{i j}, i=1, \ldots, m$, to produce $s$ outputs $y_{r j}, r=1, \ldots, s$. In the following analysis there are two inputs $(m=2)$ and two outputs $(s=2)$. The linear programming problems used to calculate the variable-specific MEA-inefficiencies for observation $\left(x_{0}, y_{0}\right)$ are determined as follows, noting that we here assume a constant returns to scale technology and use a combined input-output orientation, simultaneously identifying improvements in all inputs and outputs: First, an ideal reference point for $\left(x_{0}, y_{0}\right)$ is found by solving the $m+s$ linear programs (one for each input and output dimension):

For each input $i$ solve for each observation $\left(x_{0}, y_{0}\right)$ :

$d_{i 0}^{*}=\min _{\lambda, d_{i 0}} d_{i 0}$

s.t. 
$\sum_{j} \lambda_{j} x_{i j} \leq d_{i 0}$

$\sum_{j} \lambda_{j} x_{(-i) j} \leq x_{(-i) 0}$

$\sum_{j} \lambda_{j} y_{r j} \quad \geq y_{r 0}$

$\mathrm{r}=1, \ldots, \mathrm{s}$

$\lambda_{j} \geq 0$

$\forall \mathrm{j}$,

where the notation $(-i)$ denotes all other input dimensions except dimension $i$.

For each output $r$ solve for each observation $\left(x o, y_{0}\right)$ :

$\partial_{r 0}^{*}=\max _{\lambda, \partial_{r 0}} \partial_{r 0}$

s.t.

$\sum_{j} \lambda_{j} x_{i j} \leq x_{i 0} \quad \mathrm{i}=1, \ldots, \mathrm{m}$

$\sum_{j} \lambda_{j} y_{r j} \quad \geq \partial_{r 0}$

$\sum_{j} \lambda_{j} y_{(-r) j} \geq y_{(-r) 0}$

$\lambda_{j} \geq 0 \quad \forall \mathrm{j}$,

where the notation (-r) denotes all output dimensions besides dimension $r$.

Combining the solutions from equations (1) and (2) above results in an ideal reference point $d^{*}=\left(d_{10}^{*}, \ldots, d_{m 0}^{*}, \partial_{10}^{*}, \ldots, \partial_{s 0}^{*}\right)$ for observation $\left(? ?_{0}, ? ? 0\right)$.

In the second step, use the ideal reference point for $(? ? 0, ? ? 0)$ calculated in the first step to solve the following program to identifying the non-radial benchmark for MEA:

$\beta_{0}^{*}=\max _{\lambda, \beta_{0}} \beta_{0}$

s.t.

$\sum_{j} \lambda_{j} x_{i j} \leq x_{i j}-\beta_{0}\left(x_{i j}-d_{i 0}^{*}\right), \quad i=1, \ldots, m$

$\sum_{j} \lambda_{j} y_{r j} \geq y_{r j}+\beta_{0}\left(\partial_{r 0}^{*}-y_{r j}\right), \quad r=1, \ldots, s$

$\lambda_{j} \geq 0$

$\forall j$.

Finally use the solution $\left(\lambda^{*}, \beta_{0}^{*}\right)$ from equation 3 to determine the vector of relative variablespecific MEA efficiency scores for observation (??0, ??0) as: 
$\left(\frac{x_{10}-\beta_{0}^{*}\left(x_{10}-d_{10}^{*}\right)}{x_{10}}, \ldots, \frac{x_{\mathrm{m} 0}-\beta_{0}^{*}\left(x_{\mathrm{m} 0}-d_{\mathrm{m} 0}^{*}\right)}{x_{\mathrm{m} 0}}, \frac{y_{10}}{y_{10}+\beta_{0}^{*}\left(\partial_{10}^{*}-y_{10}\right)}, \ldots, \frac{y_{\mathrm{s} 0}}{y_{\mathrm{s} 0}+\beta_{0}^{*}\left(\partial_{\mathrm{s} 0}^{*}-y_{\mathrm{s} 0}\right)}\right)$.

Note that in the analysis a set of observations $N$ consists of individual banks observed in one of three years combined into one analysis (a so-called window analysis). The use of three-year windows is a compromise between boosting the sample size (since there are not enough observations to facilitate analysis within each year separately) and still only comparing observations that can reasonably be argued to be comparable. This is like the approach used in Asmild and Matthews (2012).

The MEA approach is illustrated for two inputs and a fixed output in Figure 3 below. The figure illustrates how the benchmark in MEA is different from the one considered in the more commonly used DEA approach, since the former is found by a proportional reduction of the potential improvements in each (here input) dimension (found using eq. 1), whereas the input reduction in the latter is proportional to the observed input values. Thus the benchmark in MEA is found in the direction of the ideal point $d^{*}$. So where DEA provides one efficiency score for the radial contraction of all inputs, MEA provides a vector of variable-specific efficiencies, highlighting the likely different improvement potential in each variable.

Figure 3: Illustration of MEA (two inputs, fixed output)

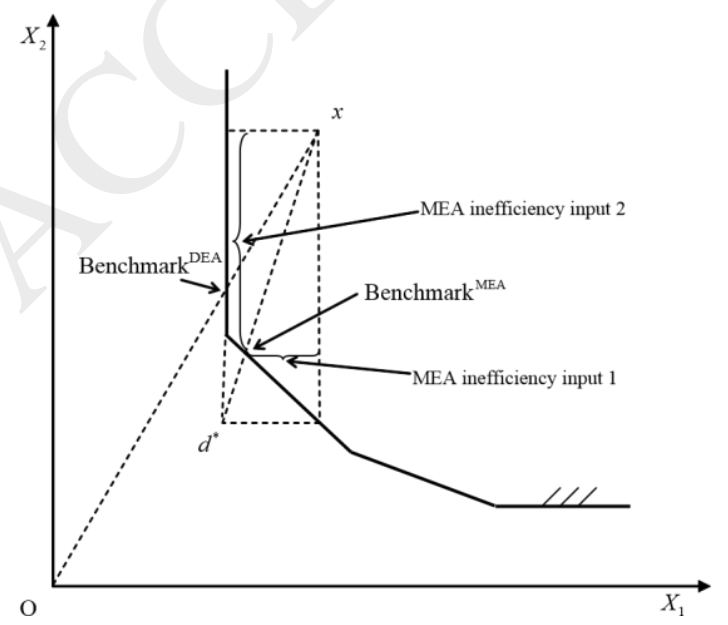




\section{Empirical exploration}

\subsection{Data}

The data set comprises 30 PCBs; six GEN1 banks, 17 GEN23 banks and 7 IBs over the period 2001-15. The data was hand-collected from the annual reports ${ }^{16}$ of the banks, obtained from individual websites and archived sources ${ }^{17}$. The conceptual difficulties of classifying assets between IBs and CBs due to the restrictions of Sharia precepts restricts the inputs and output variables that can be used in common models of efficiency. Conventional banks hold shortterm debt instruments as part of their earning assets portfolio both for risk reduction through diversification and to reduce liquidity risk. But these types of assets are forbidden to Islamic banks which are expected to hold asset-backed instruments, known as Sukuk, that theoretically have an uncertain rate of return, rather than a known coupon. Theoretically IBs are meant to operate funding and assets on a profit-loss sharing (PLS) basis but, many IBs use non-PLS instruments to deal with withdrawal risk and the moral hazard associated with PLS financing (see Abedifar et al, 2013 for a discussion). The complexity of the Islamic modes of financing makes it difficult to make a matching of assets between IBs and CBs. The simple transposition of the familiar intermediation approach of Sealey and Lindley (1977) may not be appropriate for a data set that includes both IBs and CBs.

We approach this problem by matching the revenue streams of the two types of banks for the outputs. Therefore, net interest earnings for conventional banks are matched against earnings from assets less profit to depositors. These include earnings from loans as well as earnings from investments and other earning assets. We refer to these revenue flows as balance sheet earnings'. The non-interest income of the CBs, which includes trading in derivatives, is

\footnotetext{
${ }^{16}$ Another reason for excluding foreign banks from the sample is because the annual statements are reported as consolidated accounts.

${ }^{17}$ The inconsistencies in the use of the data from Bankscope for identifying the balance sheet items of Islamic banks were highlighted by participants of the FIFC 2017 Lancaster University conference. An earlier version of this paper utilised Bankscope data to 2012. In the light of participants' comments and the unavailability of Bankscope to update the data, we instead utilised data from individual annual accounts.
} 
matched to the fee income of the IBs, which will include the conventional activity of custody, financial advice and financial services. These revenue flows are in the following denoted as 'off-balance sheet earnings' 18 .

The inputs are less problematic with operational costs being largely similar in concept for the two types of banks. For inputs we use personnel expenses (labour costs) and non-personnel expenses (Other Costs). All variables are deflated by the CPI. The data is presented in five time windows each comprising three years. Descriptive statistics of the variables, across all the years in the data set (2001-2015) and across each time window are shown for the GEN1 banks, the GEN23 banks and the IBs in Table 2 below. What is particularly notable about the input side is the rise in labour costs both in real absolute terms, and relative to other costs for the IBs and GEN23 banks. This reflects the increased use of technology and its effect on the productivity of human capital in banking (Isik and Hassan, 2002).

Table 2. Descriptive Statistics of Model Variables Mean (St Dev)

\begin{tabular}{|l|l|l|l|l|l|}
\hline Type & Period & Labour Costs & Other Costs & $\begin{array}{l}\text { Off-balance sheet } \\
\text { earnings }\end{array}$ & $\begin{array}{l}\text { Balance sheet } \\
\text { earnings }\end{array}$ \\
\hline \multirow{5}{*}{ GEN1 } & $2001-15$ & $997.1(387.6)$ & $811.3(490.6)$ & $1168(433.0)$ & $2767(1618)$ \\
& & & & & \\
& $2001-03$ & $564.5(192.5)$ & $420.0(199.9)$ & $910.0(419.4)$ & $1034(303.1)$ \\
& $2004-06$ & $715.2(214.3)$ & $550.6(308.3)$ & $959.2(317.2)$ & $1379(417.5)$ \\
$2007-09$ & $962.6(191.1)$ & $670.7(238.6)$ & $1205(365.6)$ & $2687(789.6)$ \\
& $2010-12$ & $1285(158.7)$ & $1205(568.8)$ & $1493(471.1)$ & $4398(1149)$ \\
$2013-15$ & $1458(213.4)$ & $1210(396.3)$ & $1269(339.8)$ & $4225(917.8)$ \\
\hline
\end{tabular}

\footnotetext{
${ }^{18}$ Revenue flows have been used in a number of studies in evaluating bank efficiency, see for example Asmild and Matthews (2012)
} 


\begin{tabular}{|l|l|l|l|l|l|}
\hline GEN23 & $2001-15$ & $498.9(408.7)$ & $527.3(497.6)$ & $754.3(524.0)$ & $1675(1332)$ \\
& $2001-03$ & $133.1(114.9)$ & $148.5(94.9)$ & $269.6(212.3)$ & $419.0(291.3)$ \\
& $2004-06$ & $241.2(142.0)$ & $246.3(123.8)$ & $507.2(278.2)$ & $790.9(353.1)$ \\
$2007-09$ & $450.3(248.5)$ & $465.7(288.7)$ & $815.8(410.3)$ & $1614(873.6)$ \\
& $2010-12$ & $745.1(376.4)$ & $819.7(497.1)$ & $1162(543.3)$ & $2663(1250)$ \\
& $2013-15$ & $924.7(397.8)$ & $956.6(630.3)$ & $2889(1252)$ & $1017(513.1)$ \\
\hline \multirow{3}{*}{ IB } & & & & & \\
& & & & & \\
& $2001-2015$ & $649.6(862.7)$ & $421.8(422.1)$ & $869.0(952.2)$ & $1847(2283)$ \\
& & & & & \\
& $2001-03$ & $192.9(240.6)$ & $166.8(171.9)$ & $330.8(364.3)$ & $541.7(673.5)$ \\
& $2004-06$ & $354.9(466.1)$ & $232.3(244.2)$ & $651.7(724.8)$ & $871.3(957.6)$ \\
& $2007-09$ & $528.6(679.1)$ & $326.6(296.2)$ & $886.6(955.7)$ & $1544(1810)$ \\
& $2010-12$ & $880.6(953.3)$ & $576.7(435.2)$ & $1310(1163)$ & $2763(2754)$ \\
& $2013-15$ & $1206(1186)$ & $755.0(538.7)$ & $3252(2869)$ & $1083(1042)$ \\
\hline
\end{tabular}

\subsection{Results}

In Table 3 below are shown the mean MEA efficiency scores for each type of bank (GEN1, GEN23, and IBs), within each of the five three-year time windows, as well as the associated standard deviations.

Table 3: Average MEA scores and estimated standard deviations of the scores

\begin{tabular}{|c|c|c|c|c|c|}
\hline \multirow[b]{2}{*}{ Period } & & \multirow[b]{2}{*}{$\begin{array}{l}\text { Labour } \\
\text { Costs }\end{array}$} & $\begin{array}{ll}\text { MEA } & \text { scores } \\
\text { (St.Dev) } & \end{array}$ & \multirow[b]{2}{*}{$\begin{array}{l}\text { Off-Balance } \\
\text { sheet } \\
\text { earnings }\end{array}$} & \multirow[b]{2}{*}{$\begin{array}{l}\text { Balance } \\
\text { sheet } \\
\text { earnings }\end{array}$} \\
\hline & & & $\begin{array}{l}\text { Other } \\
\text { Costs }\end{array}$ & & \\
\hline $2001-2003$ & $\begin{array}{l}\text { GEN1 } \\
\text { GEN23 } \\
\text { IB } \\
\end{array}$ & $\begin{array}{l}0.748(0.044) \\
0.840(0.113) \\
0.826(0.107)\end{array}$ & $\begin{array}{l}0.860(0.101) \\
0.821(0.105) \\
0.840(0.114)\end{array}$ & $\begin{array}{l}0.808(0.132) \\
0.720(0.237) \\
0.736(0.235)\end{array}$ & $\begin{array}{l}0.674(0.114) \\
0.757(0.168) \\
0.689(0.195)\end{array}$ \\
\hline 2004-2006 & $\begin{array}{l}\text { GEN1 } \\
\text { GEN23 } \\
\text { IB }\end{array}$ & $\begin{array}{l}0.720(0.032) \\
0.833(0.089) \\
0.817(0.120)\end{array}$ & $\begin{array}{c}0.796(0.107) \\
0.822(0.078) \\
0.852(0.111)\end{array}$ & $\begin{array}{l}0.691(0.159) \\
0.728(0.155) \\
0.776(0.195)\end{array}$ & $\begin{array}{l}0.680(0.149) \\
0.810(0.111) \\
0.763(0.171)\end{array}$ \\
\hline
\end{tabular}




\begin{tabular}{|l|l|l|l|l|l|}
\hline \multirow{2}{*}{$2007-2009$} & GEN1 & $0.730(0.044)$ & $0.844(0.058)$ & $0.712(0.128)$ & $0.764(0.103)$ \\
& GEN23 & $0.793(0.086)$ & $0.809(0.085)$ & $0.738(0.144)$ & $0.723(0.132)$ \\
& IB & $0.825(0.133)$ & $0.890(0.124)$ & $0.794(0.270)$ & $0.787(0.201)$ \\
\hline & & & & & \\
$2010-2012$ & GEN1 & $0.786(0.067)$ & $0.817(0.066)$ & $0.564(0.151)$ & $0.758(0.097)$ \\
& GEN23 & $0.816(0.075)$ & $0.829(0.084)$ & $0.679(0.164)$ & $0.763(0.124)$ \\
& IB & $0.815(0.096)$ & $0.864(0.096)$ & $0.668(0.279)$ & $0.797(0.158)$ \\
\hline $2013-2015$ & GEN1 & $0.812(0.067)$ & $0.865(0.070)$ & $0.769(0.076)$ & $0.857(0.084)$ \\
& GEN23 & $0.813(0.082)$ & $0.841(0.098)$ & $0.795(0.116)$ & $0.822(0.117)$ \\
& IB & $0.826(0.121)$ & $0.878(0.129)$ & $0.775(0.253)$ & $0.810(0.252)$ \\
\hline
\end{tabular}

The results show a mixed picture for the window periods outside the GFC. In general, on the output side, IBs appear to outperform GEN1 banks but there is no consistent pattern when compared with GEN23 banks. Similarly, with input efficiency IBs appear to perform better in the utilisation of non-labour resources, from 2004 but show a mixed picture for labour costs. However, to formally test whether there are significant differences in the efficiencies between the groups (types of banks) it should be noted that the distributional properties of MEA efficiency scores, like their DEA counterparts, are not known. Therefore, we in the following use the Kruskal-Wallis test, the non-parametric equivalent to one-way ANOVA, for comparing the group distributions.

In Table 4 below are shown the Kruskal -Wallis test statistics (KW) and the corresponding pvalues (p), for the tests for whether the MEA efficiencies for all three types of banks come from the same distribution, for a given variable and time window.

Table 4: Kruskal-Wallis rank sum test and corresponding p-values (p) for comparison of the variable-specific MEA-scores between the three types of banks.

All test statistics are evaluated in chi-square distributions with two degrees of freedom.

\begin{tabular}{|c|c|c|c|c|c|}
\hline Time window & & $\begin{array}{l}\text { Labour } \\
\text { Costs }\end{array}$ & $\begin{array}{l}\text { Other } \\
\text { Costs }\end{array}$ & $\begin{array}{l}\text { Off- } \\
\text { balance } \\
\text { sheet } \\
\text { earnings }\end{array}$ & $\begin{array}{l}\text { Balance } \\
\text { sheet } \\
\text { earnings }\end{array}$ \\
\hline 2001-2003 & $\begin{array}{l}\text { KW } \\
\mathbf{p}\end{array}$ & $\begin{array}{l}10.2 * * * \\
(0.006)\end{array}$ & $\begin{array}{l}1.98 \\
(0.371)\end{array}$ & $\begin{array}{l}0.797 \\
(0.671)\end{array}$ & \begin{tabular}{|l}
5.13 \\
0.077
\end{tabular} \\
\hline
\end{tabular}




\begin{tabular}{|c|c|c|c|c|c|}
\hline 2004-2006 & $\begin{array}{l}\text { KW } \\
\mathbf{p}\end{array}$ & $\begin{array}{l}21.94 * * * \\
(0.000)\end{array}$ & $\begin{array}{l}2.94 \\
(0.231)\end{array}$ & $\begin{array}{l}3.03 \\
(0.220)\end{array}$ & $\begin{array}{l}8.28 * * \\
(0.016)\end{array}$ \\
\hline 2007-2009 & $\begin{array}{l}\text { KW } \\
\mathbf{p}\end{array}$ & $\mid \begin{array}{l}10.9 * * * \\
(0.004)\end{array}$ & $\begin{array}{l}11.4 * * * \\
(0.003)\end{array}$ & $\begin{array}{l}11.4^{* *} \\
(0.035)\end{array}$ & $\begin{array}{l}5.92 \\
(0.052)\end{array}$ \\
\hline 2010-2012 & $\begin{array}{l}\text { KW } \\
\mathbf{p}\end{array}$ & $\begin{array}{l}2.42 \\
(0.298)\end{array}$ & $\begin{array}{l}5.30 \\
(0.071)\end{array}$ & $\begin{array}{l}6.79 * * \\
(0.034)\end{array}$ & $\begin{array}{l}2.93 \\
(0.231)\end{array}$ \\
\hline 2013-2015 & $\begin{array}{l}\mathrm{KW} \\
\mathrm{p}\end{array}$ & $\begin{array}{l}0.635 \\
(0.728)\end{array}$ & $\begin{array}{l}4.26 \\
(0.119)\end{array}$ & $\begin{array}{l}3.92 \\
(0.141)\end{array}$ & $\begin{array}{l}2.74 \\
(0.254)\end{array}$ \\
\hline
\end{tabular}

From Table 4 we observe that there are mainly significant differences between the distributions of the efficiency scores for the different bank types in the time window of 2007-2009, that is, during the financial crisis. The differences here are significant for three of the four variables, either strongly significant (1\%), for Labour Costs and Other Costs, or weakly significant (5\%) for Off-balance sheet earnings ${ }^{19}$. The other strongly significant difference between the types of banks is for Labour Costs in the time windows of 2001-2003, and 2004-2006.

We next investigate further, exactly where the differences between the bank types seen above come from, by conducting pairwise comparisons of the distributions of the efficiency scores in the relevant time window 2007-2009, as shown in Table 5 below:

Table 5: Kruskal-Wallis rank sum test for comparison of MEA-scores between pairs of bank types and corresponding p-values for the time window 2007-2009.

All test statistics are evaluated in chi-square distributions with one degree of freedom.

\begin{tabular}{|c|c|c|c|c|c|}
\hline 2007-2009 & & $\begin{array}{l}\text { Labour } \\
\text { Costs }\end{array}$ & $\begin{array}{l}\text { Other } \\
\text { Costs }\end{array}$ & $\begin{array}{l}\text { Off- } \\
\text { balance } \\
\text { sheet } \\
\text { earnings }\end{array}$ & $\begin{array}{l}\text { Balance } \\
\text { sheet } \\
\text { earnings }\end{array}$ \\
\hline GEN1/GEN23 & $\begin{array}{l}\text { KW } \\
\text { p }\end{array}$ & $\begin{array}{l}36.4 * * * \\
(0.000)\end{array}$ & $\begin{array}{l}10.8^{* * * *} \\
(0.005)\end{array}$ & $\begin{array}{l}9.56^{* * *} \\
(0.008)\end{array}$ & $\begin{array}{l}3.61 \\
(0.165)\end{array}$ \\
\hline
\end{tabular}

\footnotetext{
${ }^{19}$ It should be noted that differences in the balance sheet earnings exist at the $10 \%$ level of significance, with the p-value at .052.
} 


\begin{tabular}{|l|l|l|l|l|l|}
\hline GEN1/IB & $\begin{array}{l}\text { KW } \\
\mathbf{p}\end{array}$ & $\begin{array}{l}18.9 * * * \\
(0.000)\end{array}$ & $\begin{array}{l}16.4 * * * \\
(0.000)\end{array}$ & $\begin{array}{l}7.80^{* *} \\
(0.020)\end{array}$ & $\begin{array}{l}9.19^{* *} \\
(0.010)\end{array}$ \\
\hline \multirow{2}{*}{ GEN23/IB } & $\begin{array}{l}\text { KW } \\
\mathbf{p}\end{array}$ & $\begin{array}{l}18.5^{* * *} \\
(0.000)\end{array}$ & $\begin{array}{l}15.47^{* * *} \\
(0.000)\end{array}$ & $\begin{array}{l}6.66^{* *} \\
(0.036)\end{array}$ & $\begin{array}{l}1.351 \\
(0.051)\end{array}$ \\
\hline
\end{tabular}

$* * *<1 \%$ significance; $* *<5 \%$ significance

In Table 5 we see that the Islamic Banks are strongly significantly different from the GEN1 banks on the efficiencies on two of the variables (Labour Costs and Other Costs) in the time window of 2007-2009, that is, during the financial crisis. They are also weakly significantly different on the two outputs (Off-balance sheet, and balance sheet earnings).

Comparing this with the average MEA efficiency scores from Table 3 (which shows that Islamic banks have higher scores for the two inputs and off-balance sheet earnings) means that we can conclude that the Islamic banks were significantly more efficient than GEN23 banks on these three variables (Labour Costs, Other Costs, and Off-balance sheet earnings) during the financial crisis. The average efficiency scores for balance sheet earnings are also higher for the Islamic banks than for the GEN1 and GEN23 banks, but not statistically significant at the $5 \%$ for differences with GEN $23^{20}$.

Finally note that the GEN1 banks were significantly less efficient on Labour Costs and on Off-balance sheet earnings than GEN23 banks in 2007-2009 window, but more efficient on Other Costs, and with no significant difference on balance sheet earnings.

\section{Discussion}

Did the Global Financial Crisis have a differential effect on Islamic Banks compared to Conventional Banks? The literature suggests yes but the effect varies from country to country so that making generalisations based on an inter-country study is questionable. This paper has explored the impact of the GFC on the efficiency of Islamic banks compared to Conventional Banks in a single country. Unlike the standard DEA, which only considers a radial measure of

\footnotetext{
${ }^{20}$ Again, the p-value is .051 and therefore only just outside the conventional level of significance $5 \%$.
} 
efficiency, we here use MEA which estimates variable specific measures of potential improvements.

In general, there is almost no significant difference in the efficiency performance of Islamic banks compared to the two groups of conventional banks throughout much of the period. However, in the time window 2007-9, which corresponds to the GFC period, the Islamic Banks are significantly more efficient than the GEN1 banks on both inputs and outputs. Compared to the GEN23 banks, the IBs are significantly more efficient on three out of the four variables (Labour Costs, Other Costs, and Off-balance sheet earnings), and also have higher, though nonsignificant, average efficiencies on Balance sheet earnings.

The common efficiency performance of IBs compared with CBs in the time windows outside the GFC period has led some to conclude that IBs merely mimic CB lending practices and fail to develop their Islamic credentials (Ahmed et al, 2006) or are faced with regulatory constraints that are inappropriate to IBs (Ahmed and Hassan, 2007). The results of this paper challenge this conclusion in the case of Bangladesh. Differences in the types of risk assets between IBs, and CBs and differences in off-balance sheet income generation show up in differences in efficiency at times of financial stress.

From an economic perspective, it is questionable whether IBs should consistently perform differently from mainstream banking. In an equilibrium, there is no reason to believe that adjusted for risk, that the performance of Islamic banks should be any different to that of conventional banks. It is only in events of an unanticipated nature that differences in the strategy and business model of the two operations will emerge to highlight differences in performance. The Global Financial Crisis is one such unanticipated event.

Our results show that IBs were better sheltered from the fallout of the GFC than CBs. Specifically, they were significantly more efficient than GEN1 banks in both revenue streams and displayed stronger managerial efficiency in being significantly more efficient in managing Labour Costs and Other Costs. Except in the case of balance sheet earnings, a similar 
performance is recorded with respect to. GEN23 banks. While the principal purpose of this paper has been to identify differences in (in-)efficiency and (in-)efficiency patterns rather than explain them, a possible explanation for the significantly higher performance by IBs in offbalance sheet earnings is that the exclusion of trading in derivative products and the different nature of the underlying assets in the use of securitization (Obaidullah, 2007) may have sheltered IB's off-balance sheet earnings during the GFC. The prohibition of a secondary market in securitized instruments means less attraction for IBs (Chapra, 2007) to engage in this area of banking. But it also means that IBs may have been less exposed to the downturn in the asset-backed securitization market during the $\mathrm{GFC}^{21}$. Weak evidence of superior performance by IBs on balance sheet earnings may be due to the CBs greater exposure to earnings from investments in the stock market. During the GFC IBs balance sheet earnings were largely from loan advances whereas CBs had significant earnings from dividends ${ }^{22}$.

What are the implications of these findings for managers and regulators? The finding that except for the period of the GFC, there are only a few instances of significant differences in efficiency between the IBs and CBs means that managers in Islamic banks need to focus on benchmarking their individual bank performance against their particular group and not be concerned with differences in operation and business models between groups. The implication is that IBs need to benchmark themselves against other IBs within the same market and regulatory environment, and not non-Islamic banks. The lessons for regulators are less clear. If IBs are shown to be better protected from negative global shocks such as the GFC, and this is shown to be the outcome of Sharia rules, it is not obvious that there are easily translatable regulations that covers all commercial banks, but regulators will be aware of the differences.

Yet these results cannot be generalised into a simple Islamic versus Conventional bank performance comparison for the reasons explored in this paper. As Beck et al (2013) report, the heterogeneous interpretation and implementation of Sharia conformable products mean that

\footnotetext{
${ }^{21}$ Abdelsalam et al (2017) show that strongly religious IBs are less likely to engage in securitization.

${ }^{22}$ The stock market was largely unaffected during 2007 but registered a slump with a fall of $22 \%$ during MayNovember 2008, see Rahaman et al (2013).
} 
cross-country comparison is invalid. Therefor the performance of IBs must be investigated on a country-by-country basis where there is the discipline of a common market environment, and a common regulatory framework. In the case of Bangladesh, we can conclude that at least in the period of the GFC, the results for Islamic banks are positive. 


\section{References}

Abdelsalam O, Elnahass M and Mollah S (2017), 'Religiosity and Bank Asset Securitization'. SSRN: https://ssrn.com/abstract=2933116 or http://dx.doi.org/10.2139/ssrn.2933116

Abduh M, Hasan S M and Pananjung A G (2013), 'Efficiency and Performance of Islamic Banks in Bangladesh', Journal of Islamic Banking and Finance, Apr-June, 94-106

Abdul-Karim M, Hassan M K, Hassan T and Mohamad S (2014), 'Capital Adequacy and Lending and Deposit Behavior of Conventional and Islamic Banks', Pacific-Basin Finance Journal, 28, 58-75

Abdul-Majid M, Saal D S and Battisti G (2010), 'Efficiency in Islamic and Conventional Banking: An International Comparison', Journal of Productivity Analysis, 34, 25-43

Abdul-Majid M, Saal D S and Battisti G (2009), 'The Impact of Islamic Banking on the Cost Efficiency and Productivity Change of Malaysian Commercial Banks', Applied Economics,

Abdul-Majid M, Mohammed No N G, and Said F F (2005), 'Efficiency of Islamic Banks in Malaysia', in Iqbal $\mathrm{M}$ and Ahmad A (eds) Islamic Finance and Economic Development, Palgrave Macmillan: New York, 94-115

Abedifar P, Molyneux P and Tarazi A (2013), 'Risk in Islamic Banking', Review of Finance, $17,2035-2096$

Ahmad A U F and Hassan M K (2007), 'Regulation and Performance of Islamic Banking in Bangladesh', Thunderbird International Business Review, 49, 2, 251-277

Ahmed E, Rahman Z and Ahmed R I (2006), 'Comparative Analysis of Loan Recovery among Nationalized, Private and Islamic Commercial Banks of Bangladesh', BRAC University Journal, 3, 1, 35-52

Akther S, Fukuyama H and Weber W L (2013), 'Estimating Two-Stage Network SlacksBased Inefficiency: An Application to Bangladesh Banking', Omega, 41, 88-96

Al-Jarrah I and Molyneux P (2005), 'Efficiency in Arabian Banking', in Iqbal M and Wilson R (Eds) Islamic Perspectives on Wealth Creation, Edinburgh University Press: Edinburgh, 97117

Ariss R T (2010), 'Competitive Conditions in Islamic and Conventional Banking: A Global; Perspective', Review of Financial Economics, 19, 101-108

Asmild M, Hougaard J L, Kronborg D and Kvist, H K (2003) Measuring inefficiency via potential improvements, Journal of Productivity Analysis, 19, 59-76.

Asmild M and Matthews K (2012), Multi-directional Efficiency Analysis of Efficiency Patterns in Chinese Banks 1997-2008, European Journal of Operational Research, 219, 434-441. 
Bader M K I, Mohamad S, Arif M \& Hassan T (2008), 'Cost, Revenue, and Profit Efficiency of Islamic versus Conventional Banks: International Evidence using Data Envelopment Analysis', Islamic Economic Studies, 15, 2, 23-75

Bangladesh Bank (2017), Annual Report 2016-2017, ttps://www.bb.org.bd/pub/publictn.php

Bashir A H M (1999), 'Risk and Profitability Measures in Islamic Banks: The Case of two Sudanese Banks', Islamic Economic Studies, 1, 1-24

Beck T, Demirgüç-Kunt A and Merrouche O (2013), 'Islamic vs Conventional Banking: Business Model, Efficiency and Stability', Journal of Banking and Finance, 37, 433-447

Bogetoft P and Hougaard J L (1999), Efficiency evaluations based on potential (nonproportional) improvements, Journal of Productivity Analysis, 12, 233-247.

Bourkhis K and Nabi M S (2013), 'Islamic and Conventional Bank's Soundness during the 2007-2008 Crisis', Review of Financial Economics, 23, 68-77

Brown K, Hassan M K, and Skully M (2007), 'Operational Efficiency and Performance of Islamic Banks', in M Kabir Hassan and Mervyn K Lewis, Handbook of Islamic Banking, Cheltenham: Edward Elgar

Chapra M U (2007), 'Challenges facing the Islamic financial industry', in M Kabir Hassan and Mervyn K Lewis, Handbook of Islamic Banking, Cheltenham: Edward Elgar

Chong B S and Liu M (2009), 'Islamic Banking: Interest Free or Interest Based?' Pacific-Basin Finance |Journal, 17, 125-144

Chowdhury, T.A. and Ahmed, K. (2009), "Performance Evaluation of Selected Private Commercial Banks in Bangladesh", International Journal of Business and Management, 4 (4)

Čihăk M and Hesse H (2010), 'Islamic Banks and Financial Stability: An Empirical Analysis', Journal of Financial Services Research, 38, 95-113

El-Gamal, M A, and Hulusi I (2005), 'Inefficiency and Heterogeneity in Turkish Banking: 1990-2000, Journal of Applied Economics, 5, 641-664

Obaidullah M (2007), 'Securitization in Islam', in M Kabir Hassan and Mervyn K Lewis, Handbook of Islamic Banking, Cheltenham: Edward Elgar

Hassan M K (2006), 'The X-Efficiency in Islamic Banks', Islamic Economic Studies, 13, 2, $49-78$

Hassan M K (1999), 'Islamic Banking in Theory and Practice: The Experience of Bangladesh', Managerial Finance, 25:5, 60-113

Hassan M and Dridi J (2010). 'The Effects of the Global Crisis on Islamic and Conventional Banks: A Comparative Study', IMF Working Paper, WP 10/201 
Hoque R and Rayhan I (2013), 'Efficiency Measurement on Banking Sector', Dhaka University Journal of Science, 61, 1-5

Hossain Raju B (2017), 'Cost and Profit Efficiency of Bangladeshi Commercial Banks: A Stochastic Frontier Approach', International Journal of Economic Behavior and Organization, 6(6), 131-142

Isik I and Hassan M K (2003), 'Financial Deregulation and Total Factor Productivity Change: An Empirical Study of Turkish Commercial Banks', Journal of Banking \& Finance, 27, 14551485

Isik I and Hassan M K (2002), 'Technical, Scale and Allocative Efficiencies of Turkish Banking Industry', Journal of Banking \& Finance, 27, 719-766

Islam, M.A., Siddiqui, M.H., Hossain K F, and Islam, M. R (2014), "Growth of Private Commercial Banks in Bangladesh", International Journal of Economics, Finance and Management Sciences, 2(1), 53-67

Islam, M.A., Siddiqui, M.H., Hossain, K.F, and Karim, L. (2013), "Performance Evaluation of the Banking Sector in Bangladesh: A Comparative Analysis", Business and Economic Research, Vol. 4, No. 1, ISSN 2162-4860 2014

Johnes J, Izzeldin M and Pappas V (2014), 'A Comparison of Performance of Islamic and Conventional Banks 2004-2009’, Journal of Economic Behavior and Organization, 103, S93S107

Mahbub T, Barker K and Matthews K (2017), 'Other People's Money: The Profitability Performance of Family Dominated Banks in Bangladesh', Cardiff Business School, Economics Working Paper.

Megginson W L (2005), "The Economics of Bank Privatization", Journal of Banking and Finance, 29, 1931-1980

Rahaman A, Hasan B and Ahsan M, (2013), 'Stock Market Performance under different Government Periods: Evidence from Bangladesh', Universal Journal of Accounting and Finance, 1: 2, 42-50

Rahman M, Bhattacharya D, Iqbal A, Islam-Khan T, and Kumar-Paul T (2009), Global Financial Crisis Discussion Series: Paper 1, Bangladesh, London: Overseas Development Institute, $\quad$ https://www.odi.org/sites/odi.org.uk/files/odi-assets/publications-opinionfiles/4319.pdf

Rashid M and Nishat A (2009), 'Disparity of Performance Indicators of Islamic Banks: Study on Bangladesh', International Journal of Business Management, 4, 8, 52-72

Robin I, Salim R and Bloch H (2018), 'Cost Efficiency in Bangladesh Banking: Does Financial Reform Matter?', Applied Economics, 50:8 891-904 
Rosman R, Abd Wahab N and Zainol Z (2014), 'Efficiency of Islamic Banks during the Financial Ceisis: An Analysis of Middle Eastern and Asian Countries', Pacific Basin Finance Journal, 28, 76-90

Safiullah Md (2010), 'Superiority of Conventional Banks and Islamic Banks of Bangladesh: A Comparative Study', International Journal of Economics and Finance, 2, 3, 199-207

Samad A (1999), 'Comparative Efficiency of the Islamic Banks vis-a-vis Conventional Banks in Malaysia, IIUM Journal of Economics and Management, 14, 2, 147-175

Sarker Md A A (1999), Islamic Banking in Bangladesh: Performance, Problems Prospects', International Journal of Islamic Financial Services, 1, 3, http://www.iefpedia.com/english/wp-content/uploads/2009/09/ISLAMIC-BANKING-

INBANGLADESH-PERFORMANCE-PROBLEMS-PROSPECTS.pdf

Sealey C W and Lindley J T (1977), 'Inputs, Outputs, and Theory of Production Cost at Depository Financial Institutions', Journal of Finance, 32, 1251-1265

Simar L and Wilson P W, (2008), 'Statistical Inference in Non-parametric Frontier Models: Recent Developments and Perspectives', in Fried H O, Lovell C A K and Schmidt S S (Eds) The Measurement of Productive Efficiency, Oxford: Oxford University Press

Simar, L. and Wilson, P. W. (2007) Estimation and inference in two-stage, semi-parametric models of production processes. Journal of Econometrics, 136, 31-64.

Srairi S A (2010), 'Cost and Profit Efficiency of Conventional and Islamic Banks in GCC Countries', Journal of Productivity Analysis, 34, 45-62

Sufian F and Kamarudin F (2014), 'Efficiency and Returns to scale in the Bangladesh Banking Sector: Empirical Evidence from the Slack-Based DEA Method', Engineering Economics, 25, $5,549-557$

Sufian F and Kamarudin (2013), 'Efficiency of the Bangladesh Banking Sector: Evidence from the Profit Function', Jindal Journal of Business Research, 2, 43-57

Yidistra D (2004), 'Efficiency in Islamic Banking: An Empirical Analysis of Eighteen Banks', Islamic Economic Studies, 12, 1, 1-20

Yousuf S, Islam A and Islam R (2014), 'Islamic Banking Scenario of Bangladesh', Journal of Islamic Banking and Finance, 2, 1, 23-29

Zaher T S and Hassan M K (2001), 'A Comparative Literature Survey of Islamic Finance and Banking', Financial Markets, Institutions \& Instruments, 10, 4, 155-199 